\title{
Effects of Satureja khuzistanica essential oils in drinking water on mortality, production performance, water intake, and organ weights in broiler chickens reared under heat stress condition
}

\author{
H. Khosravinia
}

Received: 12 November 2014 /Revised: 20 February 2015 / Accepted: 23 February 2015 / Published online: 20 March 2015

(C) The Author(s) 2015. This article is published with open access at Springerlink.com

\begin{abstract}
An experiment was conducted to examine the effects on mortality, production performance, water intake (WI), and organ weight of Satureja khuzistanica essential oil (SkEO) using 720 1-day-old Arian broiler chicks in a 42-day trial. Experimental treatments were addition of 0 ( (ontrol $^{-}$), $200,300,400$, and $500 \mathrm{mg} / \mathrm{L} \mathrm{SkEO} \mathrm{or} 500 \mathrm{mg} / \mathrm{L}$ polysorbate $80\left(\right.$ control $\left.^{+}\right)$into drinking water. The birds were kept under natural ambient temperatures 4 to $6{ }^{\circ} \mathrm{C}$ above standard recommendation from days 22 to 42 of age. Addition of SkEO into drinking water at 200 and $500 \mathrm{mg} / \mathrm{L}$ decreased weight gain $(P<0.05)$ of the birds from days 29 to 35 of age with no differences in feed intake (FI) and feed conversion ratio (FCR) compared to control groups $(P>0.05)$. Supplementation of drinking water with $200,300,400$, and $500 \mathrm{mg} / \mathrm{L}$ SkEO resulted in a $0.47,4.40,8.60$, and $12.93 \%$ decrease in WI, respectively, from days 1 to 42 of age. The calculated European broiler index was greater for the birds received $400 \mathrm{mg} / \mathrm{L}$ of SkEO in their drinking water compared with that of the other birds $(P<0.05)$. Pancreas percentage was increased for the birds received 200 to $500 \mathrm{mg} / \mathrm{L} \mathrm{SkEO}$ at days 21 and 42 of age compared with that of the control ${ }^{-}$birds $(P<0.05)$. The gall bladder weight was $17.56,40.50,12.16$, and $38.73 \%$ greater for the birds received 200, 300, 400, and $500 \mathrm{mg} / \mathrm{L} \mathrm{SkEO}$ compared with that of the control ${ }^{-}$birds, respectively. The results showed that an addition of $400 \mathrm{mg} /$ L SkEO into drinking water for heat-stressed broiler chickens improves economic efficiency possibly by promoting digestion process, creating miniscule improvement in FCR and lowered mortality rate.
\end{abstract}

H. Khosravinia $(\bowtie)$

Department of Animal Science, Faculty of Agriculture, Lorestan University, P.B. 465, Khorramabad 6813717133, Lorestan, Iran

e-mail:khosravi_fafa@yahoo.com
Keywords Broiler chicken $\cdot$ Heat stress $\cdot$ Satureja khuzistanica . Water intake $\cdot$ Zootechnical performance

\section{Introduction}

Extreme ambient temperature is probably the most prevalent environmental stressor adversely affecting welfare, health, and production economics in broiler industry (Borges et al. 2004). The major consequence of heat stress in growing birds is depressed weight gain occurring mainly due to decreased feed intake and elevated energy expenditure to reduce body temperature (Lott 1991; May and Lott 1992; Belay and Teeter 1993). Therefore, exploration of any avenue toward heat stress relief which improves feed and water intake may offer a thermoregulatory and performance advantage to heat-stressed broilers. Many studies have focused on diet modifications to alleviate hot environmental conditions for heat-stressed broilers. In most of these studies, supplementing diets or drinking water with vitamins (Mckee and Harrison 1995), electrolytes (Borges et al. 2003, 2004; Ahmed and Sarwar 2006), probiotics (Zulkifli et al. 2000), prebiotics (Riad et al. 2010), or organic acids (Goksoy et al. 2010) was the main approach suggested to minimize the impact of heat stress in broilers. Recent findings show that the use of phytogenic feed additives alleviates the harmful effect of heat stress in broiler chickens (Zeinali et al. 2011; Suderman and Solikhah 2011). Zeinali et al. (2011) reported that dietary supplementation of selenium and turmeric powder had a beneficial effect on health and plasma lipids in heat-stressed broiler chicken. Suderman and Solikhah (2011) showed that inclusion of Pluchea indica L. leaf meal in diet $(20 \mathrm{~g} / \mathrm{kg})$ improved weight gain, feed intake, and water intake, but not feed conversion ratio, in heat-stressed broiler chicks. 
Satureja khuzistanica Jamzad is a plant well-known for its remedial properties in traditional medicine (Zargari 1990). The aerial parts of $S$. khuzistanica collectively contain up to $3 \%$ of an essential oil spectacularly rich in carvacrol (up to $94 \%$ ) (Khosravinia et al. 2013). Carvacrol is a phenolic, caustic, and bitter-tasting compound with good stability (Lide 1998) demonstrating antioxidant (Quiroga and Asensio 2015) and antimicrobial (Burt 2004) effects. Therefore, the S. khuzistanica essential oils (SkEO) exhibited antioxidant (Abdollahi et al. 2003; Radonic and Milos 2003), antiviral (Yamasaki et al. 1998), antibacterial (Azaz et al. 2002), and antifungal (Skocibusic and Bezic 2004) effects mainly in experiments conducted under standard managerial practices and normal environmental conditions.

However, experimental evidence on effects of administration of phytogenic extracts to the avian exposed to various environmental stressors such as heat-stressed birds is scarce. Therefore, this study aimed to examine the effects of SkEO on productive performance, mortality, and certain organ weights in broiler chickens exposed to seasonal extreme environmental temperatures during days 21 to 42 of age.

\section{Materials and methods}

Preparation of essential oil

The aerial parts of $S$. khuzistanica were manually harvested during the flowering stage of the plant in Khorraman farm, Khorramabad, Iran. ${ }^{1}$ The collected materials were air dried at ambient temperature under shade and hydrodistilled using a clevenger-type apparatus for $5 \mathrm{~h}$, giving a yellow oil in $3 \%$ yield. The oils were dried over anhydrous sodium sulfate and stored at $4{ }^{\circ} \mathrm{C}$. A sample of the bulk was analyzed based on the methods used by Hadian et al. (2011) and the composition is presented in Table 1.

\section{Experimental flock}

A total number of 720 1-day-old Arian broiler chicks were obtained from a commercial hatchery and housed in a concrete floor, cross-ventilated windowless shed. The chicks were randomly assigned to 36 pens $(100 \times 180 \mathrm{~cm})$ arranged in six replicate blocks at flocking density of 12 birds per $\mathrm{m}^{2}$. Corn and soybean meal based diets and water were provided to the birds for ad libitum consumption throughout the experiment (Table 2). The shed was equipped with wet pad-and-fan cooling system to reduce the ambient temperature. Nonetheless, during days 21 to 42 of experiment, the average

\footnotetext{
${ }^{1}$ The plant was already identified by the Department of Botany of the Research Institute of Forests and Rangelands (TARI), Tehran. A voucher specimen (No. 58416) has been deposited at the Herbarium of TARI.
}

Table 1 Essential oil composition of Satureja khuzistanica

\begin{tabular}{lll}
\hline Compound & RI1 & Composition (\%) \\
\hline$\alpha$-Thujene & 925 & $0.24 \pm 0.14$ \\
$\alpha$-Pinene & 933 & $0.15 \pm 0.05$ \\
Myrcene & 981 & $0.26 \pm 0.19$ \\
$\alpha$-Terpinene & 1013 & $0.24 \pm 0.12$ \\
$p$-Cymene & 1017 & $1.26 \pm 0.86$ \\
Limonene & 1026 & $0.13 \pm 0.04$ \\
(Z)- $\beta$-ocimene & 1036 & $0.54 \pm 0.08$ \\
$\gamma$-Terienene & 1053 & $0.74 \pm 0.23$ \\
trans-Sabinene hydrate & 1081 & $0.17 \pm 0.02$ \\
Terpinen-4-ol & 1163 & $\operatorname{tr}$ \\
$\alpha$-Terpinolene & 1175 & $0.42 \pm 0.45$ \\
Thymol & 1266 & $\operatorname{tr}$ \\
Carvacrol & 1282 & $92.16 \pm 0.46$ \\
Thymyl acetate & 1329 & $\operatorname{tr}$ \\
$\beta$-Caryophyllene & 1425 & $0.16 \pm 0.01$ \\
$\alpha$-Humulene & 1427 & $\operatorname{tr}$ \\
$\beta$-Bisabolene & 1501 & $\operatorname{tr}$ \\
trans- $\beta$-Bisabolene & 1522 & $0.10 \pm 0.01$ \\
\hline
\end{tabular}

$R I 1$ retention indices determined relative to n-alkanes (C6-C24) on a DB5 GC column, $\operatorname{tr}$ trace $(<0.05 \%)$

temperature during day and night hours ranged from 32 to 35 and 28 to $30^{\circ} \mathrm{C}$, respectively. Therefore, it was considered that the birds were exposed to seasonal extreme ambient temperature from day 21 of age onwards.

The effects of six experimental treatments consisting supplementation of drinking water with 0 ( control $\left.^{-}\right), 200,300$, 400 , and $500 \mathrm{mg} / \mathrm{L} \mathrm{SkEO} \mathrm{or} 500 \mathrm{mg} / \mathrm{L}$ polysorbate 80 (control $^{+}$) were examined in six replicates of 20 birds each. Polysorbate 80 used as an emulsifying agent to disperse SkEO in water at a $1: 1$ ratio $(v / v)$. Mortality was recorded all through the experiment upon occurrence. Body weight gain, FI, and WI were measured weekly, and their data were used to calculate data on FCR and FI:WI ratio and a European broiler index (EBI) as (Euribrid 1994);

$$
\begin{aligned}
\mathrm{EBI} & =(\text { viability, } \% \times \text { live weight, } \mathrm{kg}) \\
& \times 100 /(\text { age of slaughtering, days } \times \text { feed intake, } \mathrm{kg})
\end{aligned}
$$

At day 21 of age, one male bird and at 42 days of age eight birds (4 males and 4 females) from each replicate pen were killed (without stunning) by slicing the carotid artery and jugular vein, bled for $120 \mathrm{~s}$, scaled at $60{ }^{\circ} \mathrm{C}$ for $90 \mathrm{~s}$, and picked using a rotary drum picker individually and eviscerated. After evisceration, the carcasses were individually weighed $(\mathrm{CW})$ and the data were presented as a percentage of live weight (CY). The weight of abdominal fat (AF), liver, pancreas, duodenum, and gall bladder were also expressed proportional to carcass weight. 
Table 2 Percentage inclusion and calculated composition of diets

\begin{tabular}{|c|c|c|c|c|}
\hline Ingredient (\%) & Prestarter, 1-7 days & Starter, 7-21 day & Grower, 22-35 days & Finisher, 36-42 days \\
\hline Corn & 53.00 & 55.35 & 57.00 & 61.00 \\
\hline Soybean meal & 25.00 & 23.12 & 22.5 & 20.5 \\
\hline Fish meal & 7.00 & 5.00 & 4.00 & 3.00 \\
\hline Soybean oil & 4.00 & 4.00 & 4.00 & 5.00 \\
\hline Wheat & 3.50 & 4.00 & 3.50 & 2.50 \\
\hline Calcium carbonate & 2.00 & 2.00 & 2.00 & 2.00 \\
\hline Wheat bran & 2.50 & 2.00 & 3.00 & 3.00 \\
\hline Dicalcium phosphate & 2.00 & 2.00 & 2.00 & 2.00 \\
\hline DL-Methoinine & 0.20 & 0.20 & 0.20 & 0.20 \\
\hline L-Lysine & 0.12 & 0.11 & 0.10 & 0.10 \\
\hline Common salt & 0.25 & 0.25 & 0.25 & 0.25 \\
\hline Mineral premix ${ }^{\mathrm{a}}$ & 0.50 & 0.50 & 0.50 & 0.50 \\
\hline Vitamin permix ${ }^{\mathrm{b}}$ & 0.75 & 0.65 & 0.55 & 0.50 \\
\hline Coccidiostat & 0.10 & 0.10 & 0.10 & 0.00 \\
\hline \multicolumn{5}{|l|}{ Calculated composition } \\
\hline $\mathrm{ME}, \mathrm{MJ} / \mathrm{kg}$ & 12.39 & 12.05 & 12.35 & 12.52 \\
\hline Crude protein, $\%$ & 22.24 & 21.15 & 20.02 & 17.63 \\
\hline Calcium, \% & 1.10 & 1.03 & 1.00 & 1.01 \\
\hline Available P, \% & 0.45 & 0.44 & 0.40 & 0.45 \\
\hline Methionine, $\%$ & 0.52 & 0.53 & 0.40 & 0.43 \\
\hline Lysine, $\%$ & 1.15 & 1.08 & 1.10 & 1.03 \\
\hline
\end{tabular}

${ }^{\text {a }}$ Mineral mix supplied per kilogram diet: Mn, $55 \mathrm{mg}$; Zn, $50 \mathrm{mg}$; Fe, $80 \mathrm{mg}$; Cu, $5 \mathrm{mg}$; Se, $0.1 \mathrm{mg}$; I, $0.18 \mathrm{mg}$

${ }^{\mathrm{b}}$ Vitamins mix supplied per kilogram diet: vitamin A, 18,000 IU; vitamin $\mathrm{D}_{3}, 4000 \mathrm{IU}$; vitamin $\mathrm{E}, 36 \mathrm{mg}$; vitamin $\mathrm{K}_{3}, 4 \mathrm{mg}$; vitamin $\mathrm{B}_{12}, 0.03 \mathrm{mg}$; thiamine, $1.8 \mathrm{mg}$; riboflavin, $13.2 \mathrm{mg}$; pyridoxine, $6 \mathrm{mg}$; niacin, $60 \mathrm{mg}$; calcium pantothenate, $20 \mathrm{mg}$; folic acid, $2 \mathrm{mg}$; biotin, $0.2 \mathrm{mg}$; choline chloride, $500 \mathrm{mg}$

\section{Statistical analysis}

The statistical model used to analyze the collected data was

$Y_{i j k l}=\mu+\mathrm{SkEO}_{i}+S_{j}+B_{k}+\varepsilon_{\mathrm{ijkl}}$,

where $Y_{i j k l}$ is the dependent variable, $\mu$ is the general mean, $\mathrm{SkEO}_{i}$ is the fixed effect of $\operatorname{SkEO}\left(i=6\right.$; control ${ }^{+}$and 0,200 , $300,400,500 \mathrm{mg} / \mathrm{L} \mathrm{SkEO}), S_{j}$ is the fixed effect of sex $(j=2)$, $B_{k}$ is the random effect of block $(j=6 ; 1,2,3,4,5$, and 6$)$ and $\varepsilon_{i j k l}$ is the residual error. For the variables evaluated at day 21 of age, the fixed effect of sex was omitted from the model. The data were analyzed using PROC MIXED of SAS 9.1 (2002). The LSD test was used for multiple treatment comparisons using the LSMEANS statement of SAS 9.1 (2002) with letter grouping obtained using the SAS pdmix 800 macro (Saxton 1998). For the different statistical tests, significance was declared at $P<0.05$. The REG procedure of SAS 9.1 (2002) was used to provide regression models for assessment of relationship between SkEO and water intake. Orthogonal polynomial contrasts were applied to test the linear or quadratic nature of the response in variables concerned to the graded levels of SkEO in drinking water (SAS Institute 2002).

\section{Results}

Supplementing SkEO at the levels of 200 and $500 \mathrm{mg} / \mathrm{L}$ in drinking water did not change average daily gain (ADG) of the birds with the single exception of days 29 to 35 of age when ADG was greater in SkEO-received birds compared with the control birds $(P<0.05$; Table 3$)$. Feed intake was similar among the birds $(P>0.05$; Table 4$)$. Feed conversion ratio tended to be lower $(3.5 \%)$ in the birds receiving $400 \mathrm{mg}$ / L SkEO than in the other birds ( $P=0.058$; Table 4$)$.

Water intake was significantly decreased by addition of SkEO into drinking water in a dose-dependent manner during all weekly periods of age $(P<0.05$; Table 5$)$. Supplementation of drinking water with SkEO linearly decreased water intake from day 1 to 42 of age (Fig. 1). A dose-response decrease was also observed in mean FI:WI ratio for all birds received SkEO in their drinking water, but the response was not as much consistent as it was for WI $(P<0.01$; Table 5). The mean mortality rate was not different for the treated birds compared 
Table 3 Effect of essential oils of Satureja khuzistanica on average daily weight gain in broiler chicken up to 42 days of age

\begin{tabular}{|c|c|c|c|c|c|c|c|c|}
\hline & \multicolumn{2}{|c|}{ Weight gain $(\mathrm{g})$} & \multicolumn{4}{|c|}{ Essential oils of $S$. khuzistanica (mg/L) } & \multirow[t]{2}{*}{$\mathrm{SEM}^{\mathrm{b}}$} & \multirow[t]{2}{*}{$P$ value } \\
\hline & Control $^{+\mathrm{a}}$ & Control $^{-\mathrm{a}}$ & 200 & 300 & 400 & 500 & & \\
\hline 1-7 days & 16.61 & 16.90 & 16.78 & 16.91 & 16.92 & 16.98 & 0.09 & 0.7981 \\
\hline $8-14$ days & 26.29 & 26.41 & 26.26 & 26.21 & 27.17 & 25.31 & 0.29 & 0.5547 \\
\hline $\begin{array}{l}15- \\
21 \text { days }\end{array}$ & 41.31 & 41.72 & 40.19 & 41.52 & 39.40 & 40.90 & 0.32 & 0.1484 \\
\hline $22-$ & 72.62 & 74.72 & 76.05 & 73.48 & 74.91 & 74.48 & 0.46 & 0.3590 \\
\hline 35 days & $81.36^{\mathrm{b}}$ & $87.72^{\mathrm{a}}$ & $87.48^{\mathrm{a}}$ & $80.00^{\mathrm{b}}$ & $85.00^{\mathrm{ab}}$ & $80.29^{\mathrm{b}}$ & 0.87 & 0.0076 \\
\hline${ }^{36-}$ days & 82.43 & 81.43 & 79.60 & 85.62 & 86.07 & 83.00 & 1.25 & 0.6865 \\
\hline 1-42 days & 53.43 & 54.81 & 54.39 & 53.96 & 55.91 & 53.49 & 0.23 & 0.2456 \\
\hline
\end{tabular}

Means within a row without a common superscript $(a, b)$ differ significantly $(P<0.05)$

${ }^{a} \mathrm{Control}^{+}$: The birds that received drinking water supplemented with $500 \mathrm{mg} / \mathrm{L}$ polysorbate 80 throughout the trial. Control ${ }^{-}$: The birds that received drinking water with no additive

${ }^{\mathrm{b}}$ Standard error of mean

to the control birds during days 1 to 21 and 22 to 42 of age ( $P>0.05$; Fig. 2). However, for pooled data overall periods, supplementation of drinking water with 300 and $500 \mathrm{mg} / \mathrm{L}$ SkEO increased mortality rate of the birds mainly in the second episode of the growing period when the birds were under heat stress.
The calculated European broiler index was greater for the birds that received $400 \mathrm{mg} / \mathrm{L}$ of SkEO in their drinking water compared to the other groups (Fig. 3). There were no significant effects of SkEO-treated water on carcass weight, carcass yield, and abdominal fat percentage in male and female birds at day 42 of age $(P>0.05$; Table 6$)$. The mean duodenum

Table 4 Effect of essential oils of Satureja khuzistanica on average daily feed intake and feed conversion ratio in broiler chicken up to day 42 of age

\begin{tabular}{|c|c|c|c|c|c|c|c|c|c|c|}
\hline & \multirow[t]{2}{*}{ Control $^{+\mathrm{a}}$} & \multicolumn{5}{|c|}{ Essential oils of $S$. khuzistanica (mg/L) } & \multirow[b]{2}{*}{$\mathrm{SEM}^{\mathrm{b}}$} & \multirow[b]{2}{*}{$P$ value } & \multicolumn{2}{|l|}{ Trend } \\
\hline & & 0 & 200 & 300 & 400 & 500 & & & Linear & Quadratic \\
\hline \multicolumn{11}{|l|}{ Feed intake (g) } \\
\hline 1-7 days & 19.26 & 19.67 & 19.40 & 19.02 & 19.19 & 19.53 & 0.104 & 0.4158 & 0.2345 & 0.2013 \\
\hline $8-14$ days & 36.62 & 36.17 & 36.45 & 37.01 & 36.50 & 36.29 & 0.114 & 0.2258 & 0.6571 & 0.7201 \\
\hline 15-21 days & 60.01 & 60.95 & 60.03 & 60.71 & 59.86 & 61.46 & 0.252 & 0.3129 & 0.5321 & 0.1234 \\
\hline 22-28 days & 136.58 & 132.36 & 133.27 & 132.07 & 132.17 & 129.78 & 0.898 & 0.2511 & 0.4561 & 0.2340 \\
\hline 29-35 days & 183.41 & 175.65 & 176.13 & 175.15 & 175.41 & 175.52 & 1.603 & 0.6742 & 0.2913 & 0.4521 \\
\hline 36-42 days & 189.77 & 199.85 & 204.82 & 210.97 & 196.04 & 214.24 & 2.754 & 0.0672 & 0.3912 & 0.1219 \\
\hline $1-42$ days & 104.27 & 104.11 & 105.08 & 105.82 & 103.18 & 106.14 & 0.466 & 0.4356 & 0.2345 & 0.0912 \\
\hline \multicolumn{11}{|c|}{ Feed conversion ratio (g feed:g gain) } \\
\hline 1-7 days & 1.141 & 1.185 & 1.158 & 1.125 & 1.135 & 1.151 & 0.007 & 0.1603 & 0.2048 & 0.4193 \\
\hline 8-14 days & 1.393 & 1.377 & 1.408 & 1.418 & 1.351 & 1.437 & 0.014 & 0.5144 & 0.2834 & 0.2006 \\
\hline $15-21$ day & 1.440 & 1.477 & 1.494 & 1.466 & 1.523 & 1.504 & 0.010 & 0.1280 & 0.2817 & 0.3510 \\
\hline 22-28 days & 1.829 & 1.824 & 1.754 & 1.798 & 1.765 & 1.745 & 0.013 & 0.1652 & 0.3461 & 0.4123 \\
\hline 29-35 days & 2.099 & 2.160 & 2.022 & 2.192 & 2.066 & 2.191 & 0.026 & 0.3171 & 0.3116 & 0.4218 \\
\hline 36-42 days & 2.369 & 2.430 & 2.592 & 2.465 & 2.278 & 2.599 & 0.042 & 0.1801 & 0.4760 & 0.1812 \\
\hline 1-42 days & 1.903 & 1.948 & 1.930 & 1.963 & 1.880 & 1.985 & 0.011 & 0.0581 & 0.1823 & 0.1456 \\
\hline
\end{tabular}

${ }^{\text {a }}$ Control $^{+}$: The birds received drinking water supplemented with $500 \mathrm{mg} / \mathrm{L}$ polysorbate 80 throughout the trial

${ }^{\mathrm{b}}$ Standard error of mean 
Table 5 Effect of essential oils of Satureja khuzistanica on water intake and water:feed ratio in broiler chicks up to 28 days of age

\begin{tabular}{|c|c|c|c|c|c|c|c|c|c|c|}
\hline & \multirow[t]{2}{*}{ Control $^{+\mathrm{a}}$} & \multicolumn{5}{|c|}{ Essential oils of $S$. khuzistanica (mg/L) } & \multirow[b]{2}{*}{ SEM $^{\mathrm{b}}$} & \multirow[b]{2}{*}{$P$ value } & \multicolumn{2}{|l|}{ Trends } \\
\hline & & 0 & 200 & 300 & 400 & 500 & & & Linear & Quadratic \\
\hline \multicolumn{11}{|c|}{ Water intake (mL/day per bird) } \\
\hline 1-7 days & $32.86^{\mathrm{a}}$ & $32.86^{\mathrm{a}}$ & $30.29^{\mathrm{b}}$ & $30.00^{\mathrm{c}}$ & $28.57^{\mathrm{d}}$ & $27.14^{\mathrm{e}}$ & 0.353 & 0.0001 & 0.0234 & 0.5691 \\
\hline 8-14 days & $97.14^{\mathrm{b}}$ & $102.86^{\mathrm{a}}$ & $94.29^{\mathrm{d}}$ & $95.71^{\mathrm{c}}$ & $92.86^{\mathrm{e}}$ & $91.43^{\mathrm{f}}$ & 0.623 & 0.0001 & 0.0023 & 0.3491 \\
\hline 15-21 day & $162.86^{\mathrm{c}}$ & $161.43^{\mathrm{d}}$ & $177.14^{\mathrm{a}}$ & $167.14^{\mathrm{b}}$ & $167.14^{\mathrm{b}}$ & $154.29^{\mathrm{e}}$ & 1.172 & 0.0001 & 0.0021 & 0.4001 \\
\hline 22-28 days & $249.00^{\mathrm{b}}$ & $257.43^{\mathrm{a}}$ & $238.86^{\mathrm{d}}$ & $242.57^{\mathrm{c}}$ & $218.57^{\mathrm{e}}$ & $215.71^{\mathrm{f}}$ & 2.572 & 0.0001 & 0.0038 & 0.7412 \\
\hline 29-35 days & $322.07^{\mathrm{a}}$ & $297.09^{c}$ & $305.19^{\mathrm{b}}$ & $278.64^{\mathrm{d}}$ & $271.43^{\mathrm{e}}$ & $257.14^{\mathrm{f}}$ & 3.685 & 0.0001 & 0.0231 & 0.4183 \\
\hline $36-42$ days & $351.00^{\mathrm{a}}$ & $328.43^{\mathrm{c}}$ & $328.71^{\mathrm{b}}$ & $314.14^{\mathrm{d}}$ & $300.00^{\mathrm{e}}$ & $281.71^{\mathrm{f}}$ & 3.758 & 0.0001 & 0.0052 & 0.3426 \\
\hline $1-42$ days & $202.49^{\mathrm{a}}$ & $196.68^{\mathrm{b}}$ & $195.75^{\mathrm{c}}$ & $188.03^{\mathrm{d}}$ & $179.76^{\mathrm{e}}$ & $171.24^{\mathrm{f}}$ & 1.810 & 0.0001 & 0.0010 & 0.7250 \\
\hline \multicolumn{11}{|c|}{ Water $(\mathrm{mL})$ : feed $(\mathrm{g})$ ratio } \\
\hline $1-7$ days & $1.71^{\mathrm{a}}$ & $1.67^{\mathrm{a}}$ & $1.56^{\mathrm{b}}$ & $1.58^{\mathrm{b}}$ & $1.49^{\mathrm{c}}$ & $1.39^{\mathrm{d}}$ & 0.020 & 0.0001 & 0.0124 & 0.5791 \\
\hline $8-14$ days & $2.65^{\mathrm{b}}$ & $2.84^{\mathrm{a}}$ & $2.56^{\mathrm{cd}}$ & $2.59^{\mathrm{c}}$ & $2.54^{\mathrm{cd}}$ & $2.52^{\mathrm{d}}$ & 0.020 & 0.0001 & 0.0183 & 0.2471 \\
\hline 15-21 days & $2.71^{\mathrm{bc}}$ & $2.65^{\mathrm{c}}$ & $2.95^{\mathrm{a}}$ & $2.76^{\mathrm{b}}$ & $2.79^{\mathrm{b}}$ & $2.51^{\mathrm{d}}$ & 0.025 & 0.0001 & 0.0251 & 0.4021 \\
\hline $22-28$ days & $1.82^{\mathrm{b}}$ & $1.95^{\mathrm{a}}$ & $1.79^{\mathrm{b}}$ & $1.84^{\mathrm{b}}$ & $1.65^{\mathrm{c}}$ & $1.67^{\mathrm{c}}$ & 0.021 & 0.0001 & 0.0028 & 0.6412 \\
\hline 29-35 days & $1.76^{\mathrm{ab}}$ & $1.69^{\mathrm{a}}$ & $1.74^{\mathrm{a}}$ & $1.60^{\mathrm{bc}}$ & $1.55^{\mathrm{cd}}$ & $1.47^{\mathrm{d}}$ & 0.023 & 0.0001 & 0.0049 & 0.2103 \\
\hline $36-42$ days & $1.85^{\mathrm{a}}$ & $1.68^{\mathrm{b}}$ & $1.62^{\mathrm{bc}}$ & $1.50^{\mathrm{c}}$ & $1.54^{\mathrm{bc}}$ & $1.32^{\mathrm{d}}$ & 0.032 & 0.0001 & 0.0131 & 0.4416 \\
\hline 1-42 days & $1.94^{\mathrm{a}}$ & $1.89^{\mathrm{ab}}$ & $1.86^{\mathrm{b}}$ & $1.78^{\mathrm{c}}$ & $1.75^{\mathrm{c}}$ & $1.61^{\mathrm{d}}$ & 0.020 & 0.0001 & 0.0217 & 0.6270 \\
\hline
\end{tabular}

${ }^{\text {a }}$ Control+: The birds that received drinking water supplemented with $500 \mathrm{mg} / \mathrm{L}$ polysorbate 80 throughout the trial. Contro $\Gamma$ : The birds that received drinking water with no additive

${ }^{\mathrm{b}}$ Standard error for overall mean

Means within a row without a common superscript $(a-f)$ differ significantly $(P<0.05)$

weight in days 21 and 42 of age was not affected $(P>0.05)$ by SkEO-treated water (Table 7). Pancreas percentage was significantly increased $(P<0.05)$ for the birds that received 200 to

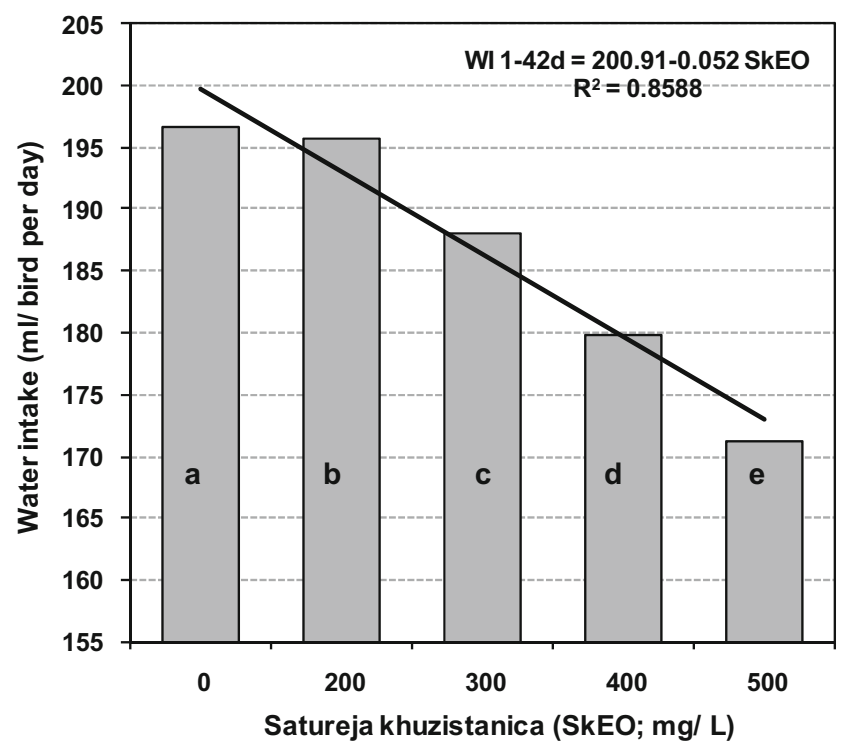

Fig. 1 Effect of Satureja khuzestanica essential oils (SkEO) on water intake (WI) in broiler chicks during days 1 to 42 of age. Means without a common superscript $(a-e)$ differ significantly $(P<0.05)$
$500 \mathrm{mg} / \mathrm{L} \mathrm{SkEO}$ at 21 and 42 days of age compared with that of the control groups. Liver percentage (as the percentage of carcass weight) was not significantly different among the treated and control birds at day 42 of age $(P<0.05)$. The relative weight of gall bladder was greater for the birds that received $500 \mathrm{mg} / \mathrm{L}$ SkEO compared to the control birds at day 42 of age $(P<0.05$; Table 7$)$.

\section{Discussion}

In this study, SkEO exhibited no promising effect on DWG of the broiler chicken through day 28 of age when the birds were maintained under normal production practices. However, in days 29 to 35, when the birds suffered from an extreme heat stress episode, SkEO-added water decreased DWG of the birds. The decreased DWG was mainly attributed to the lowered water intake which imposed a great challenge to the birds because they needed to drink more water to overcome their disturbed homeothermic state (Lara and Rostagno 2013). In a study, supplementation of drinking water with high doses of SkEO (ranging from 500 to $2500 \mathrm{mg} / \mathrm{L}$ ) adversely affected production performance of broiler chickens from days 1 to 28 of age (Khosravinia et al. 2013). When the dose of SkEO in drinking water were reduced below $500 \mathrm{mg} / \mathrm{L}$, the birds 


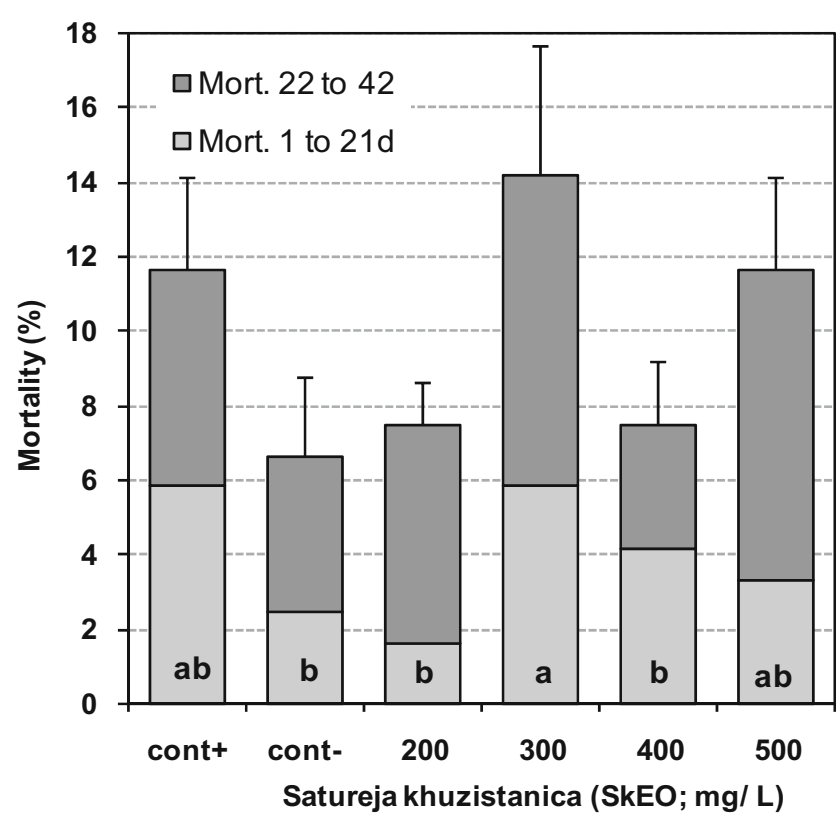

Fig. 2 Effect of essential oils of Satureja khuzistanica (SkEO) on mortality of broiler chickens during 1 to 21 and 22 to 42 days of age. The letters inside the columns represent significant difference for mortality percent among treatments for 1 to 42 days of age. The error bars show standard error for mean mortality over 1 to 42 days. Means without a common superscript $(a-b)$ differ significantly $(P<0.05)$

received $500 \mathrm{mg} / \mathrm{L}$ SkEO in the first 28 days of age compensated their weight gain afterwards. These findings were inconsistent with the results of Lee et al. (2003) who reported a $2 \%$ increase in average daily gain of broiler chicken by inclusion of $0.2 \mathrm{~g}$ per $\mathrm{kg}$ carvacrol in the diet. Addition of tymole, an isomer of carvacrol, at the same dose caused a $3 \%$ decrease in ADG (Lee et al. 2003). The same researchers did not report water intake of the treated birds. However, the differences in the results could be explained by physiological status of the birds. In the current study, birds were not raised in standard conditions. The inconsistency in the results of current study with those reported by the other researchers could be also explained by the fact that in this experiment $\mathrm{SkEO}$ was added to the drinking water, while in the other studies the active components of SkEO (such as carvacrol) were mainly included in the diet. In agreement with the findings of the current study, Basmacioglu et al. (2004) reported that dietary oregano extract (a natural product rich in carvacrol) at $0.15 \mathrm{~g} / \mathrm{kg}$ decreased ADG in broiler chicken by $2 \%$ compared to the control birds. However, when the applied dose doubled $(0.3 \mathrm{~g} / \mathrm{kg})$, ADG was increased as much as $2 \%$ compared to the control group.

The results on FI and FCR in this study were not consistent. Therefore, no dose-dependent or an age-associated response could be pointed out. The unchanged FI for the treated birds was in agreement with the findings of Lee et al. (2003) but disagreed with the results reported by Basmacioglu et al. (2004). The later researchers found that dietary inclusion of

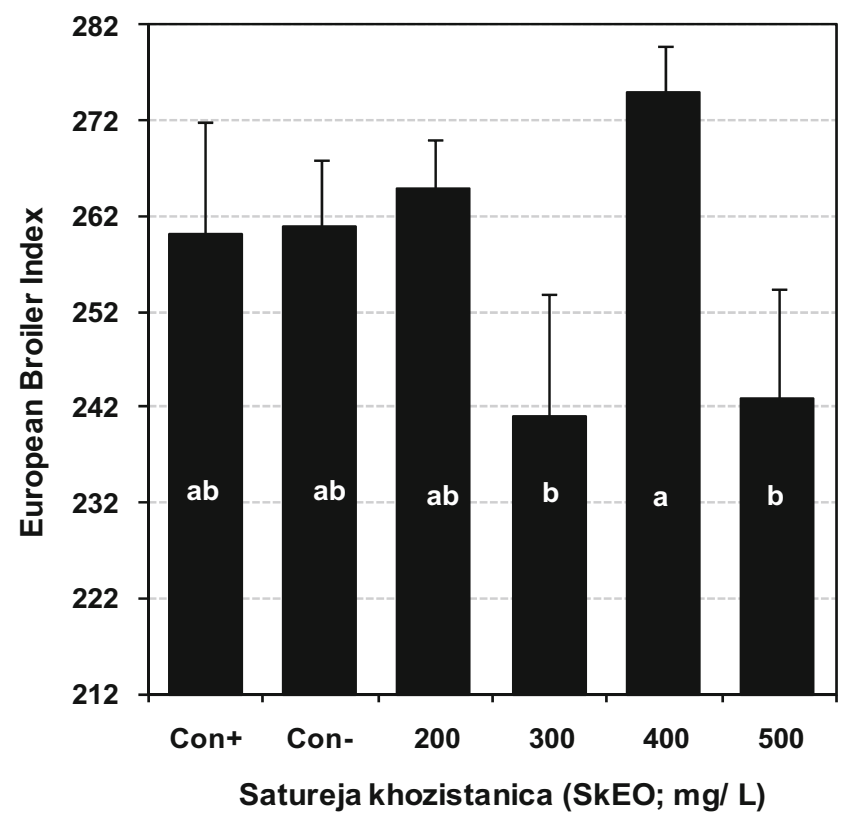

Fig. 3 Effect of essential oils of Satureja khuzistanica (SkEO) on average European broiler index in broiler chicks at 42 days of age. Means without a common superscript $(a-b)$ differ significantly $(P<0.05)$

$0.2 \mathrm{~g} / \mathrm{kg}$ carvacrol and $0.15 \mathrm{~g} / \mathrm{kg}$ oregano extract caused $2 \%$ increase and $6 \%$ decrease in FI of the birds compared with the relevant control groups, respectively. In contrast to the published results, in this study, adding SkEO into drinking water had no effect on FCR. These results disagree findings of Lee et al. (2003), Basmacioglu et al. (2004), and Abdel-Wareth et al. (2012) who reported decreased FCR for the birds fed with diets containing carvacrol or carvacrol-rich essential oils. The inconsistencies observed in the findings of different experiments may be attributed to the differences in management practices applied in the experimental flocks and physiological state of the birds. In the present study, SkEO decreased WI in all treated birds. Such effect has been already assigned to the flavor of water (Khosravinia et al. 2013). The bitter and pungent taste of carvacrol and possibly other principle components of SkEO caused a significant drop in water intake. Water is involved in every aspect of broiler metabolism, playing important roles in regulating body temperature, digesting food, and eliminating body wastes. At normal temperatures, poultry consume at least twice as much water as feed. Under heat stress, water intake increases (Quinteiro-Filho et al. 2012; Lara and Rostagno 2013). It seems that the caustic taste of water did not allow the treated birds to increase their WI when they were exposed to heat stress. Therefore, a dose-dependent decrease in mean FI:WI ratio was observed (Fig. 1). Unfortunately, effects of flavors on chicken performance have not been investigated in detail. Because, most researchers believe that broilers may not actually respond to the flavors as compared with mammals (Moran 1982). It was shown that dietary inclusion of carvacrol in broiler chicks reduced feed intake by modulating appetite of the birds (Lee et al. 2003). In 
Table 6 Effect of essential oils of Satureja khuzistanica on carcass weight (CW; g), carcass yield (CY; \%), abdominal fat-to-carcass weight ratio (AF:CW) in broiler chicks at 42 days of age

\begin{tabular}{|c|c|c|c|}
\hline & $\mathrm{CW}$ & $\mathrm{CY}$ & AF:CW \\
\hline \multicolumn{4}{|l|}{ Males } \\
\hline $\mathrm{Control}^{+\mathrm{a}}$ & 1662.6 & 40.54 & 2.442 \\
\hline 0 & 1594.2 & 31.69 & 1.969 \\
\hline 200 & 1651.0 & 38.00 & 2.294 \\
\hline 300 & 1661.3 & 35.50 & 2.131 \\
\hline 400 & 1652.2 & 32.00 & 1.940 \\
\hline 500 & 1683.6 & 38.75 & 2.300 \\
\hline SEM $^{\mathrm{b}}$ & 14.449 & 1.202 & 0.067 \\
\hline$P<F$ & 0.1581 & 0.1859 & 0.2125 \\
\hline \multicolumn{4}{|l|}{ Trends } \\
\hline Linear & 0.4510 & 0.2871 & 0.4511 \\
\hline Quadratic & 0.2672 & 0.3212 & 0.1873 \\
\hline \multicolumn{4}{|l|}{ Females } \\
\hline Control $^{+a}$ & 1408.0 & 41.77 & 2.970 \\
\hline 0 & 1454.2 & 36.58 & 2.500 \\
\hline 200 & 1413.6 & 45.00 & 3.127 \\
\hline 300 & 1328.4 & 38.08 & 2.866 \\
\hline 400 & 1398.2 & 37.92 & 2.722 \\
\hline 500 & 1409.6 & 36.25 & 2.557 \\
\hline $\mathrm{SEM}^{\mathrm{b}}$ & 15.238 & 1.203 & 0.077 \\
\hline$P<F$ & 0.2936 & 0.2910 & 0.1581 \\
\hline \multicolumn{4}{|l|}{ Trends } \\
\hline Linear & 0.3321 & 0.3870 & 0.6517 \\
\hline Quadratic & 0.3642 & 0.3912 & 0.1271 \\
\hline
\end{tabular}

${ }^{\text {a }}$ Control ${ }^{+}$: The birds received drinking water supplemented with $500 \mathrm{mg} / \mathrm{L}$ polysorbate 80 throughout the trial

${ }^{\mathrm{b}}$ Standard error of mean agreement with the conclusions made by Lee et al. (2004), findings of the present study also questioned the assumption that phytogenic extracts improve the palatability of diet (Windisch et al. 2008; Costa et al. 2013). The great attention currently focused on administration of essential oils and other phytogenic products to poultry urges further investigation on response of avian species to flavors in water and feeds.

Mortality always represents a major economic loss in broiler flocks. It is usually greater in broiler flocks exposed to extreme environmental temperatures compared to those maintained in normal conditions. Water intake is an important determinant in mortality rate in heat-stressed birds (Bruno et al. 2011). Water intake increases in heat-stressed birds to maintain thermoregulatory balance (Bruno and Macari 2002), because heat stress increases water loss via exhalation as a mean to cool down body temperature (Zhang et al. 2012). In the current study, it was speculated that the decreased water intake was due to the bitter taste of carvacrol resulted in greater mortality rates in treated birds. Such a speculation became a reality as the mortality rate increased in the birds received 300 and $500 \mathrm{mg} / \mathrm{L}$ SkEO when they were exposed to extreme ambient temperature in days 21 to 42 of age.

No single production criterion can perfectly reveal the economic output of a broiler flock. Researchers have tried to pool the fractional influence of many production criteria in an index to compare performance of different flocks. The index created by Euribrid (1994) is calculated based on final body weight, FCR, and mortality. The calculated index for the treated birds with $400 \mathrm{mg} / \mathrm{L}$ of SkEO through drinking water was greater compared to other groups. The diminutive advantages of water treated with $400 \mathrm{mg} / \mathrm{L}$ SkEO in DWG, improved FCR in days 1 to 42 of age and lowered mortality rate especially during days 22 to 42 of age was reflected as an improved

Table 7 Effect of essential oils of Satureja khuzistanica on relative weight of duodenum and pancreas (at 21 and 42 days) and relative weight of liver and bile bladder (at 42 day) in broiler chickens

\begin{tabular}{|c|c|c|c|c|c|c|c|c|c|c|}
\hline & \multirow[t]{2}{*}{ Control $^{+\mathrm{a}}$} & \multicolumn{5}{|c|}{ Essential oils of $S$. khuzistanica $(\mathrm{mg} / \mathrm{L})$} & \multirow[t]{2}{*}{ SEM $^{\mathrm{b}}$} & \multirow[t]{2}{*}{$P$ value } & \multicolumn{2}{|l|}{ Trends } \\
\hline & & 0 & 200 & 300 & 400 & 500 & & & Linear & Quadratic \\
\hline & \multicolumn{10}{|c|}{ Gram per $100 \mathrm{~g}$ body weight at 21 days } \\
\hline Duodenum & 1.412 & 1.689 & 1.628 & 1.625 & 1.483 & 1.507 & 0.045 & 0.3120 & 0.2072 & 0.1176 \\
\hline \multirow[t]{2}{*}{ Pancreas } & $0.549^{\mathrm{ab}}$ & $0.492^{\mathrm{b}}$ & $0.579^{\mathrm{a}}$ & $0.547^{\mathrm{ab}}$ & $0.528^{\mathrm{ab}}$ & $0.545^{\mathrm{ab}}$ & 0.012 & 0.0192 & 0.3519 & 0.0172 \\
\hline & \multicolumn{10}{|c|}{ Gram per $100 \mathrm{~g}$ body weight at 42 days } \\
\hline Duodenum & 1.180 & 1.218 & 1.269 & 1.356 & 1.223 & 1.178 & 0.023 & 0.1927 & 0.3451 & 0.2431 \\
\hline Pancreas & $0.332^{\mathrm{a}}$ & $0.302^{\mathrm{b}}$ & $0.332^{\mathrm{a}}$ & $0.329^{\mathrm{a}}$ & $0.332^{\mathrm{a}}$ & $0.340^{\mathrm{a}}$ & 0.006 & 0.0121 & 0.0345 & 0.3391 \\
\hline Liver & 3.783 & 3.639 & 3.831 & 3.566 & 3.583 & 3.500 & 0.065 & 0.6670 & 0.5100 & 0.4310 \\
\hline Gall bladder & $0.094^{\mathrm{ab}}$ & $0.074^{\mathrm{b}}$ & $0.087^{\mathrm{ab}}$ & $0.104^{\mathrm{a}}$ & $0.083^{\mathrm{ab}}$ & $0.102^{\mathrm{a}}$ & 0.004 & 0.0146 & 0.0341 & 0.1021 \\
\hline
\end{tabular}

${ }^{\text {a }} \mathrm{Control}^{+}$: The birds received drinking water supplemented with $500 \mathrm{mg} / \mathrm{L}$ polysorbate 80 throughout the trial

${ }^{\mathrm{b}}$ Standard error of mean

Means within a column without a common superscript $(a-b)$ differ significantly $(P<0.05)$ 
EBI index. These results suggest that $400 \mathrm{mg} / \mathrm{L}$ can be recommended as the dose for addition of SkEO into drinking water for broiler chickens.

In the current study, CW and CY were not affected by treatments in either male or female birds. These results were expected as carcass weight is mainly associated with pre-slaughter weight but carcass yield is mainly correlated to body composition among many other factors. However, it was anticipated that SkEO exerts a considerable impact on abdominal fat percentage. Case et al. (1995) reported that dietary inclusion of carvacrol affected fat metabolism in broiler chicken as shown by decreased abdominal fat (AF). In broiler chicken, lipids and triglycerides in particular are stored in the abdominal cavity (Saadoun and Leclercq 1987). There is a general postulation that almost all the fat built up in broiler adipose tissue including abdominal fat is synthesized in the liver or derived from the diet (Griffin et al. 1992; Hermier 1997). The results on AF disagree with the findings of Khosravinia et al. (2013) who reported that supplementation of drinking water with SkEO (500 to $2500 \mathrm{mg} / \mathrm{L}$ ) significantly reduced abdominal fat in both male and female birds raised under normal conditions.

In conclusion, the present study revealed that administration of $\mathrm{SkEO}$ at $400 \mathrm{mg} / \mathrm{L}$ through drinking water to heat-stressed broiler chickens improves economic efficiency of broiler flocks possibly through promoting the digestion process, creating minute improvement in FCR and lowered mortality rate.

Acknowledgments Fruitful collaboration of Dr. A. Salehnia, Khorraman Company, Lorestan, Iran, in providing Satureja khuzistanica essential oils is gratefully acknowledged.

Open Access This article is distributed under the terms of the Creative Commons Attribution License which permits any use, distribution, and reproduction in any medium, provided the original author(s) and the source are credited.

\section{References}

Abdel-Wareth AAA, Kehraus S, Hippenstiel F, Südekum KH (2012) Effects of thyme and oregano on growth performance of broilers from 4 to 42 days of age and on microbial counts in crop, small intestine and caecum of 42-day-old broilers. Anim Feed Sci Technol 178:198-202

Abdollahi M, Salehnia A, Mortazavi SH, Ebrahimi M, Shafiee A, Fouladian F, Keshavarz F, Sorouri S, Khorasani R (2003) Antioxidant, antidiabetic, antihyperlipidemic, reproduction stimulatory properties and safety of essential oil of Satureja khuzestanica in rat in vivo: a toxicopharmacological study. Med Sci Monit 9:331-335

Ahmed T, Sarwar M (2006) Dietary electrolyte balance: implications in heat stressed broilers. Worlds Poult Sci J 63:638-653

Azaz D, Demirci F, Satil F, Kurkcuoglu M, Baser KH (2002) Antimicrobial activity of some Satureja essential oils. Z Naturforsch 57:817-821

Basmacioglu H, Tokusogluo O, Ergul M (2004) The effects of oregano and rosemary essential oils or alpha-tocopheryl acetate on performance and lipid oxidation of meat enriched with n-3 PUFAs in broilers. S Afr J Anim Sci 34:197-210

Belay T, Teeter RG (1993) Broiler water balance and thermobalance during thermoneutral and high ambient temperature exposure. Poult Sci 72:116-124

Borges SA, Fischer DA, Silva AV, Ariki J, Hooge DM, Cummings KR (2003) Dietary electrolyte balance for broiler chickens exposed to thermonutral or heat stress environments. Poult Sci 82:428-435

Borges SA, Fischer DA, Silva AV, Majorka A, Hooge DM, Cummings KR (2004) Physiological responses of broiler chicken to heat stress and dietary electrolyte balance (sodium plus potassium minus chloride, milliequivalants per kilogram). Poult Sci 83: $1551-1558$

Bruno LDG, Macari M (2002) Ingestão de água: mecanismos regulatórios. In: Macari M, Furlan RL, Gonzales E (eds) Fisiologia aviária aplicada à frangos de corte. FUNEP, Jaboticabal, pp 201-208

Bruno LDG, Maiorka A, Macari M, Furlan RL, Givisiez PEN (2011) Water intake behavior of broiler chickens exposed to heat stress and drinking from bell or and nipple drinkers. Rev Bras Cienc Avic 13:147-152

Burt S (2004) Essential oils: their antibacterial properties and potential applications in food-a review. Int J Food Microbiol 94: 223-253

Case GL, He L, Mo H, Elson CE (1995) Induction of geranyle pyrophosphatase activity by cholesterol-suppressive isoprenoids. Lipids 30:357-359

Costa LB, Luciano FB, Miyada VS, Gois FD (2013) Herbal extracts and organic acids as natural feed additives in pig diets. S Afr J Anim Sci 43:181-193

Euribrid BV (1994) Technical information for Hybro broilers. Euribrid Poultry Breeding Farm, Boxmeer, p 22

Goksoy EO, Aksit M, Kirkan S (2010) The effects of organic acids and Origanum onites supplementations on some physical and microbial characteristics of broiler meat obtained from broilers kept under seasonal heat stress. Kafkas Univ Vet Fak Derg 16:41-46

Griffin HD, Guo K, Windsor D, Butterwith SC (1992) Adipose tissue lipogenesis and fat deposition in leaner broiler chickens. J Nutr 122: 363-368

Hadian J, Mirjalili MH, Kanani MR, Salehnia A, Ganjipoor P (2011) Phytochemical and morphological characterization of Satureja khuzistanica Jamzad populations from Iran. Chem Biodivers 8:902-915

Hermier D (1997) Avian lipoprotein metabolism: an update on "Lipoprotein metabolism and fattening in poultry". J Nutr 127: 805-808

Khosravinia H, Ghasemei S, Rafiei AE (2013) The effect of savory (Satureja khuzistanica) essential oils on performance, liver and kidney functions in broiler chickens. J Anim Feed Sci 22:50-55

Lara LJ, Rostagno MH (2013) Impact of heat stress on poultry production. Animals 3:356-369

Lee KW, Everts H, Kappert HJ, Frehner M, Losa M, Beynen AC (2003) Effects of dietary essential oil components on growth performance, digestive enzymes and lipid metabolism in female broiler chickens. Br Poult Sci 44:450-457

Lee KW, Everts H, Beynen AC (2004) Essential oils in broiler nutrition. Int J Poult Sci 3:738-752

Lide DR (1998) Handbook of chemistry and physics, 87th edn. Boca Raton, FL: CRC Press, pp 3-346

Lott BD (1991) The effect of feed intake on body temperature and water intake of male broilers during heat exposure. Poult Sci 70:756-759

May JD, Lott BD (1992) Feed and water intake patters of broilers at high environmental temperatures. Poult Sci 71:331-336

Mckee JS, Harrison PC (1995) Effects of supplemental ascorbic acid on the performance of broiler chickens exposed to multiple concurrent stressors. Poult Sci 74:1772-1785

Moran ETJr (1982) Comparative nutrition of fowl and swine. The gastrointestinal system. University of Guelph. pp 148-195 
Quinteiro-Filho WM, Gomes AV, Pinheiro ML, Ribeiro A, Ferraz-DePaula V, Astolfi-Ferreira VC, Ferreira AJ, Palermo-Neto J (2012) Heat stress impairs performance and induces intestinal inflammation in broiler chickens infected with Salmonella enteritidis. Avian Pathol 41:421-427

Quiroga PR, Asensio CM (2015) Antioxidant effects of the monoterpenes carvacrol, thymol and sabinene hydrate on chemical and sensory stability of roasted sunflower seeds. J Sci Food Agric 95(3):471-479

Radonic A, Milos M (2003) Chemical composition and in vitro evaluation of antioxidant effect of free volatile compounds from Satureja montana L. Free Radic Res 37:673-679

Riad SA, Safaa HM, Mahamad FR, Siam SS, El-Minshawy HA (2010) Influence of probiotic, prebiotic and or yeast supplementation in broiler diets on the productivity, immune response and slaughter traits. J Anim Poult Prod 1:45-60

Saadoun A, Leclercq B (1987) In vivo lipogenesis of genetically lean and fat chicken: effects of nutritional state and dietary fat. J Nutr 117: 428-435

SAS Institute (2002) SAS/STAT ${ }^{\circledR}$ guide for personal computers. Version 9.1 edition. SAS Institute, Inc, Cary

Saxton AM (1998) A macro for converting mean separation output to letter grouping in Proc Mixed. Pages 1243-a264 in Proc. 23rd SAS User Group Intl. SAS Institute, Cary, NC
Skocibusic M, Bezic N (2004) Phytochemical analysis and in vitro antimicrobial activity of two Satureja species essential oils. Phytother Res 18:967-970

Suderman A, Solikhah SH (2011) Performance and meat cholesterol content of broiler chickens fed Pluchea indica L. leaf meal reared under stress condition. Media Peternakan, April, 2011, hlm. 64-68

Windisch W, Schedle K, Plitzner C, Kroismayr A (2008) Use of phytogenic products as feed additives for swine and poultry. $\mathrm{J}$ Anim Sci 86:140-148

Yamasaki K, Nakano M, Kawahata T, Mori H, Otake T, Ueba N, Oishi I, Inami R, Yamane M, Nakamura M, Murata H, Nakanishi T (1998) Anti-HIV-1 activity of herbs in Labiatae. Biol Pharm Bull 21:829-833

Zargari A (1990) Medicinal plants, 4th edn. Tehran University Publications, Tehran, pp 42-45

Zeinali A, Kermanshahi H, Riasi A, Farhangfar H, Sarir H, Ziaie H (2011) Effects of sodium selenite and turmeric powder on thyroid hormones and plasma lipids of broiler chickens reared under heat stress condition. Glob Vet 6:237-240

Zhang ZY, Jia GQ, Zuo JJ, Zhang Y, Lei J, Ren L, Feng DY (2012) Effects of constant and cyclic heat stress on muscle metabolism and meat quality of broiler breast fillet and thigh meat. Poult Sci 91:2931-2937

Zulkifli IN, Abdullah NM, Azrin M, Ho YW (2000) Growth performance and immune response of two commercial broiler strains fed diets containing Lactobacillus cultures and oxytetracycline under heat stress conditions. Br Poult Sci 41:593-597 